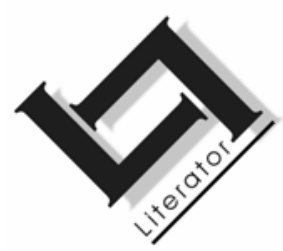

\title{
Shaping the self: A Bildungsroman for girls?
}

\author{
Idette Noomé \\ Department of English \\ University of Pretoria \\ PRETORIA \\ E-mail: inoome@postino.up.ac.za \\ idette.noome@up.ac.za
}

\section{Abstract:}

\section{Shaping the self: A Bildungsroman for girls?}

This article proposes that two alternative forms of the "Bildungsroman" developed from circa 1860 to 1960, featuring young female protagonists and aimed at girls as a readership.

To explore this proposition, the article initially focuses on three girls' series to see whether they meet the criteria for classification as a "Bildungsroman": the South African "Soekie" series written in Afrikaans by Ela Spence, the well-known Canadian "Anne of Green Gables" series by L.M. Montgomery, and the German "Pucki" series by Magda Trott. In these series girls have to learn through experience as they move toward happiness and maturity. Secondly, the article explores the presentation of the female quest, as well as some development options "in parallel" in such novels as Louisa May Alcott's now classic "Little women" and "Good wives".

The article concludes that some novels for girls move towards an exploration of personal development from childhood to maturity, but that the criteria for the "Bildungsroman" should be adjusted to include forms other than the single novels and novels focused on one protagonist that are more typical of the "male" "Bildungsroman". It also suggests that the criteria for maturity, self-actualisation and social integration need qualification in the "female" version of this genre. 


\section{Opsomming:}

\section{Die vorming van die self: 'n Bildungsroman vir meisies?}

Hierdie artikel beredeneer die stelling dat daar tussen omstreeks 1860 en 1960 twee alternatiewe vorme van die "Bildungsroman met jong vroulike protagoniste en gemik op meisies as lesers" ontwikkel het.

Om hierdie stelling te toets, is in die artikel eerstens gefokus op drie meisiereekse om vas te stel of hulle aan die klassifikasiekriteria van die "Bildungsroman" voldoen: die Suid-Afrikaanse "Soekie"-reeks, geskryf in Afrikaans deur Ela Spence, die bekende Kanadese "Anne of Green Gables"-reeks deur L.M. Montgomery, en die Duitse "Pucki"reeks deur Magda Trott. In hierdie reekse moet meisies uit hulle ervaringe leer in hulle strewe na geluk en volwassenheid. Tweedens word die vroulike soeke en ontwikkelingsmoontlikhede "as parallelle" ondersoek, in romans soos Louisa May Alcott se nou reeds klassieke "Little women" en "Good wives".

Daar is bevind dat sommige romans vir meisies neig om die persoonlike ontwikkeling van kindsbeen tot volwassenheid te ondersoek, maar dat die "Bildungsroman"-kriteria aangepas moet word om ander vorme in te sluit buiten die enkelroman en die roman wat fokus op een protagonis. Laasgenoemde vorme is meer tipies van die "manlike" "Bildungsroman". Daar word ook voorgestel dat die kriteria vir volwassenheid, self-aktualisering en sosiale integrasie in die "vroulike" weergawe van hierdie genre gekwalifiseer behoort te word.

\section{Defining the Bildungsroman}

Abrams (1981:121) translates the German terms Bildungsroman and Erziehungsroman somewhat loosely as "novel of formation" or "novel of education" respectively. In such novels, the subject is "the development of the protagonist's mind and character, as he passes from childhood through varied experiences - and usually through a spiritual crisis - into maturity and the recognition of his identity and role in the world" (Abrams, 1981:121).

Similarly, Suzanne Hader (1996:s.p.) describes a Bildungsroman as

... most generally, the story of a single individual's growth and development within the context of a defined social order. The growth process, at its root a quest story, has been described as both 'an apprenticeship to life' and a 'search for meaningful existence within society' ... The process of maturity is long, arduous, and gradual, consisting of repeated clashes between the protagonist's needs and desires and the views and judgments enforced by an unbending social order. ... Eventually, the spirit and values of the social order become manifest in 
the protagonist, who is then accommodated into society. The novel ends with an assessment by the protagonist of himself and his new place in that society.

As George Lukács quoted in Scholtz's (1992:437) article in Cloete (1992) has pointed out, most novels, of course, do deal with individuals and some kind of inner conflict, conflict with other characters or their environment (including the social milieu). If conflict is present, it is obvious that a possibility of some form of growth in the character(s) exists. However, as opposed to novels focused on incident, an adventure or a particular conflict, the novel of development/formation/education, the Bildungsroman, tends to focus primarily on the change in the protagonist (from youth to maturity), who, by the end of the novel, has developed a distinct personality and has become sufficiently mature to cope with life (Scholtz, 1992:440). The (German) origins of this type of novel lie within the 17th- and 18th-century Pietism, the sentimentalpsychological epistolary novel, and the didactic theories of Jean Jacques Rousseau (Scholtz, 1992:440). This kind of novel displays an autobiographical tone. ${ }^{1}$

Scholtz (1992:441) distinguishes more specifically between the Bildungsroman and the Erziehungsroman. He argues that the Bildungsroman, which he refers to as the "leerjareroman", looks at the character's growth more generally, while the Erziehungsroman (what Scholtz calls the "pedagogiese roman") focuses on a deliberate inculcation (often by a master) of life lessons via a particular pedagogic model. In this regard Scholtz (1992:441) cites a novel by Pestalozzi, Lienhard and Gertrud, as an example. In girls' literature, Louisa May Alcott's Eight cousins (Alcott, 1940 [1875]) and its sequel Rose in bloom (Alcott, 1927 [1876]) come to mind as explicit explorations of a pedagogic method and its results. ${ }^{2}$

Von Wilpert (1979:28) regards the term Entwicklungsroman as the most inclusive of these terms, describing it as follows:

1 James Joyce's Portrait of the artist as a young man (1916) and D.H. Lawrence's Sons and lovers (1913) are well-known examples in English that display this autobiographical bent. Of the books discussed in this article, Alcott's Little women and Good wives are held to be autobiographical, and Montgomery's Anne and Emily series contain autobiographical elements. this kind of pedagogic novel has fallen out of fashion to the point where it is arguably extinct. 
[Ein] Roman, der in sehr bewußter und sinnvoller Komposition den inneren und äußeren Werdegang e[ines] Menschen von den Anfängen bis zu e[iner] gewissen Reifung der Persönlichkeit mit psychologischer Folgerichtigkeit verfolgt und die Ausbildung vorhandener Anlagen in der dauernden Auseinandersetzung mit den Umwelteinflüssen in breitem kulturellem Rahmen darstellt (Von Wilpert, 1979:218)3.

Von Wilpert (1979:218), like Scholtz (1992:440), stresses the level of maturity reached by the protagonist, but qualifies this maturity as “... e[inen] Stand gewisser Vollkommenheit, der dem subjektiven Idealbild des Dichters und seiner Zeit entspricht"4.

Von Wilpert (1979:96) also regards the Bildungsroman as a depiction of the influence of the objective cultural world and personal environment on the psychological maturation and harmonious education of mental-spiritual abilities (character, the will) of the protagonist towards an unfolding of the personality as a whole. His definition of the Erziehungsroman (Von Wilpert, 1979:243) is similar to Scholtz's (1992:441) description of the "pedagogiese roman".

For the purposes of the article, the term Bildungsroman is used in its broadest sense to include all these subtler distinctions, since this is the term most familiar to readers.

In view of the focus of the article, it is noticeable that the above definitions by Abrams, Hader and others refer to the protagonist as "he". This does not seem to be merely a generic "he". Literary histories and classifications of this genre of novel in critical discussions suggest that the genre does indeed appear to be dominated by male protagonists. Historically, the early German examples (described in Ried, 1972:122), such as K.P. Moritz's Anton Reiser and Goethe's Wilhelm Meister's Lehr- und Wanderjahre, have male protagonists. Well-known examples in English, such as Dickens's David Copperfield (1850), Joyce's Portrait of the artist as a young man (1916) and D.H. Lawrence's Sons and lovers

3 (a) novel, which follows, with psychological accuracy with regard to developmental sequences, the interval and external development of a person from his beginnings to a certain maturity of his personality in a very conscious and purposeful composition, and which depicts the enhancement of existing gifts in the constant conflict with environmental influences within a broad cultural framework (own translation - IN).

4 "a state of a certain perfection that corresponds with the subjective ideal and mental picture held by the author and his time" (own translation - IN). 
(1913) continue this tradition. The question then arises whether there is any Bildungsroman that features a female protagonist, and whether such a "female" Bildungsroman would operate in the same way as the "male" versions. 5

In order to explore this question, the following characteristics were used as criteria to classify a book or books as Bildungsroman:

- a single character's passage from childhood to maturity (adulthood);

- varied experiences from which the protagonist learns;

- a moral/ethical/spiritual crisis of a personal nature;

- some clash and/or engagement with the expectations of society; and

- a maturity which includes some conscious recognition of the protagonist's identity and self-actualising role in the world (ending with temporary closure or an epiphany).

As I began my search for a Bildungsroman featuring a girl, my thoughts turned to individual books and series featuring female protagonists that I had loved, since in my memory these protagonists had certainly "grown" and become mature. However, upon rereading these books, I found that many of these old favourites resisted such easy classification, and demanded that I rethought both the novels and the criteria.

\section{Focus of the article}

The argument developed in this article contends that "female" forms of the Bildungsroman do exist. Consequently this article explores the idea that the Bildungsroman written with girls in mind can, firstly, be a series rather than a one-off novel or, secondly, can follow other permutations, such as exploring the Bildung of more than one protagonist simultaneously ("in parallel"). The article also problematises the last criterion by examining what self-actualisation consists of in these novels. In order to explore these contentions

5 While Von Wilpert's (1979) description, cited previously, refers to Mensch (human/ person) and therefore allows for the possibility of a female protagonist, the other glossaries of literary terms and definitions cited use the pronoun "he", and none of the examples cited in any of these works feature a female protagonist. I could find no previous discussion of this issue, in relation to either adult female or girls' literature. 
both selected series and a limited number of individual novels from between 1860 and 1960 are examined.

The choice of texts for discussion mainly from between 1860 (Alcott's texts were published in 1868 and 1871) and 1960 (the last of the Soekie series was published in 1955) was mainly dictated by the fact that this hundred-year span produced most novels that could potentially be described as Bildungsromane. From the late 1950s onward, series focusing on one character, covering personal growth from childhood to maturity in early adulthood, as well as series focusing on maturity and a social dimension included, have become rare. One could speculate that this phenomenon could be ascribed both to the series' apparently didactic aspects and their depiction of domestic relationships that were no longer regarded as politically correct after the 1960s. Furthermore, a more gritty "realism" in children's literature had become more fashionable.

The first four criteria mentioned previously had to be applied fairly stringently to limit the discussion to the one genre under investigation, while the fifth criterion was interrogated in the discussion to some extent. Hence, many single (one-off) books had to be excluded because they do not cover the growth span set out in the criteria, or feature both a boy and a girl protagonist. The selection of this period as the heyday of this type of writing is not meant to imply that novels written earlier or later could not meet the criteria, but the scope of the discussion had to be limited, particularly in view of the fact that books in three languages were discussed. Two of the series were selected from cultural spheres with an established children's and adult literary tradition (English and German), and one from a then emerging tradition of children's literature (in South Africa in Afrikaans) to show that a cross-cultural trend in this type of writing was present.

In order to explore the contention that a series can function as an extended Bildungsroman, I have focused on three popular girls' series written between 1908 and 1955. The first, which has been read throughout the world, is L.M. Montgomery's Anne of Green Gables series of eight books, written in Canada from 1908 to 1939.6

6 Most of the Anne series remains in print. The series has also become immensely popular in Japan and Korea since World War II, and in the 1950s was regarded as presenting a liberal heroine in "Anne of the Red Hair", as she became known to Japanese and Korean readers. Popular television series (also aired in South Africa) in the 1990s reinforced this popularity. 
The second, Ela Spence's Soekie series, written in the early 1950s, is a South African series of six books in Afrikaans. The third, a German series of twelve books, written somewhere in the 1930s or 1940s by Magda Trott, is about a girl nicknamed Pucki. 7 Where apposite, other individual books and series by Montgomery and Trott are briefly referred to in order to confirm the findings regarding the main texts under review.

Louisa May Alcott's classic Little women and Good wives were examined to explain the concept of the presentation of female Bildung "in parallel". The immense popularity of these works by Alcott continues and ensures that the discussion of these works remains topical, even though they are more than a century old. 8 Alcott's very popularity makes it important to recognise her ongoing influence. In this regard, Charles Strickland (1985:3) comments:

As a writer, and an extremely influential one at that, she served to perpetuate the values of Victorian domesticity to subsequent generations. Rare is the American girl who has not read one or more of Alcott's books during the highly impressionable preadolescent and adolescent years. Alcott's fiction thus has served to shape the attitudes of subsequent generations of women toward the sensitive issues of women's roles and family life. 9

$7 \quad$ No dates appear in any of the books, but the series was already in its 19th edition by the late 1960s and 1970s, when I acquired them, and the clothing represented in the illustrations suggests this era. The complete exclusion of any mention of World War II would suggest pre-war production, especially as the Goldköpfchen series by the same author explicitly mentions the war.

8 Snap surveys of my (South African) Honours students in the last three years have confirmed that almost all the female students and some of the male students in these classes have read these works. Adult responses to papers on Alcott at three conferences in South Africa and in Atlanta (USA) indicated that this readership is indeed both male and female. The popularity of these two works has been further boosted by three film versions, the most recent featuring Winona Ryder as the main character, Jo March.

$9 \quad$ Strickland (1985:3) adds: "Her influence may in fact serve to explain, in part at least, the strange persistence of Victorian values among Americans, despite the nearly unanimous declaration of intellectuals that those values are no longer relevant to life in the twentieth century." While admittedly many child readers cannot interrogate this influence (for better or worse), it must also be recognised that Alcott herself was highly subversive, and that some of her influence may be strongly positive. Alcott's realism was groundbreaking in children's literature in 1868. 
A limited number of "single" books read in English, Afrikaans and German confirmed the selection of the period under discussion as the heyday of the types of books that I contend are part of the Bildungsroman tradition. This list does not claim to be exhaustive, but it points to the types of books that are freely available in public and school libraries in South Africa.

Judy Blume's (1998 [1970]) Are you there, God? It's me, Margaret is an example of a single book that deals with a female protagonist in her eleventh and twelfth year. Because the book covers three issues in reasonable detail (the onset of puberty, an increased awareness of boys and a nascent awareness of different religions), it does not attempt to cover the protagonist's growth in all aspects or from childhood to socially integrated maturity in early adulthood. This does not detract from the book's value or appeal, but it does disqualify it from classification as a Bildungsroman. Margaret Mahy's (1985) novel for teens, The catalogue of the universe, also covers a limited time span - a few weeks after the completion of school - and features a boy and a girl as the protagonists. Similarly, books by a Norwegian author widely read in German, Berte Bratt, in the 1960s and 1970s, such as Alle nennen mich Pony (Bratt s.a. (I)) and Hab Mut, Katrin (Bratt, s.a. (II)) tend to focus on a particularly problematic year or 18 months in a female protagonist's teens. Books such as South African author Elsabe Steenberg's Bergpad na Eden (1969), Wolf ja, wolf nee (1978a), An-Alleentjie (1978b), Waar is Pappa se panfluit? (1981), Slapende honde miaau nie (1986) and Wêreld in wêreld deur (1988) also had to be excluded, either because they focused on a limited time span in a child's life, or on a limited range of problems (ambitious parents, the death of a parent or parents, being an orphan, paralysis, imagination), or because there is both a male and a female protagonist, as in Bergpad na Eden (1969)10 and An-Alleentjie (1978b).

Several series available within the period under discussion also had to be excluded. A series such as the syndicate-produced Nancy Drew series (see Nancy Drew s.a. (a); s.a.(b)) was not suitable, first, because, although the series features a female protagonist, it does not focus on her personality, but on her adventures and "sleuthing". Second, Nancy does not grow - she remains a flat (albeit exciting)

10 It was tempting to consider Bergpad na Eden for inclusion, because the intriguing flashback technique used by the author does give insight into the female protagonist's earlier childhood. However, the death of the girl at the end does not allow for her growth into a socially integrated role. 
character perpetually in her late teens (old enough to have a driver's licence, but still living at home in the more than 156 titles ${ }^{11}$ in the series, until the Nancy Drew on Campus series took off in the last decade). ${ }^{12}$ The South African Saartjie series by Bettie Naudé (1994) is also an adventure-focused series, and was excluded for similar reasons. School series (for example, the South African Maasdorp series by Stella Blakemore ${ }^{13}$, Enid Blyton's St Clare's and Malory Towers series ${ }^{\mathbf{1 4}}$, or the German translation of the St Clare's series as the immensely popular Hanni und Nanni series were also not included in this discussion, because, while the girls do "grow up" in such series, the focus is on specific lessons learnt by several girls within a school ethos, rather than on individual maturing to the level posited by the Bildungsroman criteria previously mentioned. The scope of the article also does not allow for any engagement with the debate on the merits of so-called formula-writing, which comes into play in the "adventure" and "school" series.

\section{A series as a possible form of the Bildungsroman}

\subsection{A series as a possible kind of Bildungsroman: L.M. Montgomery's Anne of Green Gables series}

At first glance, the first novel in the Anne series, Anne of Green Gables (Montgomery, 1976 [1908]) very loosely conforms to the first criterion for a Bildungsroman, in that the protagonist moves from childhood to a nominal maturity at sixteen. (In the fin de siècle setting of the book on Prince Edward Island, Canada, sixteen is regarded as "grown up"). However, the scale of the personal conflict

11 http://www.nancydrewsleuth.com

12 Smith (2002:42-67) points out that Nancy "evolves" in her various incarnations as the series was written in the 1930s, rewritten from 1959 to 1977 and in another style from 1978 to 1986, but that this "evolution" (devolution?) is one from an independent and active heroine to a pretty girl who is a model of middle-class conformism and, in the latest versions, teenage angst. This change in Nancy is not a result of character change in the protagonist in one or more novels, but a consequence of changes to the syndicate formula that makes the Nancy Drew series sell. Obviously, this is not the kind of change implied in the criteria for the Bildungsroman.

13 Blakemor's (1971) Kobie regeer is one of the series.

14 The twins at St Clare's (Blyton, 1947 [1941]) and First Term at Malory Towers (Blyton, 1948 [1946]) are two examples from this series. 
is severely limited, and genuine engagement with the expectations of society is somewhat in doubt.

Anne, who is an orphan, is introduced to the reader as a "child of about eleven, garbed in a very short, very tight, very ugly dress of yellowish white wincey" with "very thick, decidedly red hair" and freckles (Montgomery, 1976 [1908]:15). The redeeming feature of this apparently unattractive waif is the "spirit and vivacity" of her "big eyes" (Montgomery, 1976 [1908]:16).

In the process which turns the ugly duckling into the elegant swan, Anne has to learn to adapt to the customs and mores governing the lives of the middle-aged spinster Marilla and her shy bachelor brother Matthew Cuthbert, who adopt Anne as a result of a mistake by the orphanage, which sent a girl instead of the boy Marilla and Matthew had asked for. She has many trials to bear, not least being her own vanity, her hot temper and a wayward imagination. She does indeed come into conflict with her society; however, it is at a level which may appear trivial to older readers (but may well be very significant to young girl readers): so, for example, most girls can identify with Anne's wish for more fashionable clothing (notably puffed sleeves) to fit in with her peers, and her despair at having hair of a colour that does not conform with the popular image of a romantic heroine, even if adult readers may consider such issues unimportant.

Her hasty temper postpones the chance of a friendship with one of her classmates, Gilbert. He dares to refer to her red hair, whispering "Carrots" in her hearing; she breaks a slate over his head (Montgomery, 1976 [1908]:96-97) and studiously ignores him for the next few years, except to compete with him at an academic level. She is even too stubborn to make peace after he has rescued her when her boat sinks while she and her friends are play-acting Tennyson - the death of Elaine (Montgomery, 1976 [1908]:186-190). Unfortunately for the attempt to classify the novel(s) as a Bildungsroman, most of her "clashes" with her world are honest mistakes rather than conscious confrontations with societal expectations. So, for example, she accidentally gets her best friend Diana drunk on Marilla's currant wine, which Anne mistakes for raspberry cordial (Montgomery, 1976 [1908]:107-109), dyes her hair green in an attempt to get it raven black (Montgomery, 1976 [1908]: 180-184), jumps on a guest in the spare bed (Montgomery, 1976 [1908]:132-133) and puts liniment into a cake (Montgomery, 1976 [1908]:147-151). Anne is generally happy to reform or change her ways once she has erred, 
as when, after her hair has turned out green, she looks squarely into the mirror, saying

l'd do penance for being wicked that way. I'll look at myself every time I come into my room and see how ugly I am. And I won't try to imagine it away, either. I never thought I was vain about my hair, of all things, but now I know I was, in spite of its being red, because it was so long and thick and curly. I expect something will happen to my nose next (Montgomery, 1976 [1908]:184).

Anne very early on adopts most of the values prescribed by her society (with the possible exception of suppressing her imagination - although, after she has frightened herself and her friend Diana too much to walk through the woods at night and has been forced to confront this self-created fear (Montgomery, 1976 [1908]:136-142), she does learn to subdue her fancies somewhat. These childlish lessons are clearly not enough to constitute the criterion of a "moral/ethical/spiritual crisis of a personal nature" set for the Bildungsroman.

If a crisis of an ethical/moral nature in her life does become evident at all, it comes when she has completed her initial training as a teacher and has won the Avery Scholarship which will enable her to study for a BA.15 She has to wrestle with herself to decide not to take up this prestigious scholarship to continue her studies, but to stay at home for a while to look after Marilla, who might become blind if she overstrains herself. (Matthew has recently died, leaving Marilla alone with a farm to run.) It is problematic in terms of the criterion that Anne's struggle is not depicted in any detail - we simply know she has a dilemma, but she makes up her mind in a few lines:

Then Anne herself went to the east gable and sat down by her window in the darkness alone with her tears and her heaviness of heart. How sadly things had changed since she had sat there the night after coming home! Then she had been full of hope and joy and the future had looked rosy with promise. Anne felt as if she had lived years since then, but before she went to bed there was a smile on her lips and peace in her heart. She had career, as Japanese and Korean readers recognised after World War II. 
looked her duty courageously in the face and found it a friend as duty ever is when we meet it frankly (Montgomery, 1976 [1908]:251).

She informs Marilla and the reader at a later stage of her decision. It is worth noting that the writer eliminates any doubts by a reader who might think this is a silly decision by applauding Anne's courage.

Even more problematic is the end of the novel - admittedly, Anne at sixteen seems quite equipped to face adult life, but her sense of identity has altered little since the beginning of the book. She has adopted the role of care-giver, giving up her own dreams (at least temporarily). Almost as a sop, the writer offers the reader a hint of future romance between Anne and her former classmate Gilbert, leaving Anne in a moment of peace and contentment, having internalised the expectations which her society held for women, and imbued them with a glamour arising from her own imagination:

Anne's horizons had closed in since the night she had sat there after coming home from Queen's; but if the path set before her feet was to be narrow she knew that flowers of quiet happiness would bloom along it. The joys of sincere work and worthy aspiration and congenial friendship were to be hers; nothing could rob her of her birthright of fancy or her ideal world of dreams. And there was always the bend in the road! (Montgomery, 1976 [1908]:256).

The rest of the series does show Anne growing older, teaching, completing her studies, becoming a wife, and eventually, despite losing her first baby within days after the birth, a mother of six.16 Her basic personality changes little in the rest of the series. The largest crises depicted in her life are arguably her decision in Anne of the

16 Anne studies away from home in Anne of the Island (Montgomery, 1937 [1915]), teaches first near home in Anne of Avonlea (Montgomery, 1983a [1909]), then takes a post as headmistress while waiting for her fiancé, Gilbert, to complete his medical studies, in Anne of Windy Willows (Montgomery, 1994 [1936]), marries and loses her first child in Anne's house of dreams (Montgomery, 1983b [1917]), and goes on to have a large family in Anne of Ingleside (Montgomery, 1965 [1939]) and Rainbow Valley (Montgomery, 1975 [1919]). In the last book in the series, Rilla of Ingleside (Montgomery, 1993 [1921]), the focus is on Rilla and the response of the local community (including Anne as a mother) to World War I and news from the front. It is worth noting that Montgomery did not write all the books of the series in sequence - she added the fourth book and the sixth book (in terms of the story) in 1936 and 1939 respectively, but wrote the two books focusing on Anne's children (books seven and eight) in 1919 and 1921. 
Island (Montgomery, 1937 [1915]) to marry Gilbert Blythe (poor but with a sense of humour) rather than Roy Gardner (handsome, rich and adoring, but rather dull) and the loss of her first child in Anne's house of dreams (Montgomery, 1983b [1917]). These are important events in the story and seldom fail to move or entertain readers, but they do not alter the protagonist's underlying character, making it difficult to regard the series as a whole as meeting all the criteria of the Bildungsroman set out above.

One can explore the last of the series, Rilla of Ingleside (Montgomery, 1993 [1921]), as presenting another female protagonist in Anne's daughter. During World War I, Rilla grows from childhood to young womanhood. She has to face the loss of her favourite brother and somewhat unwillingly takes on a war baby. A number of factors make a classification of the book as Bildungsroman problematic, however. The character does grow up and becomes more responsible, but, although her world view has broadened and deepened considerably, she does not come to a radically new understanding of herself. Mere incidents and Rilla's romance crowd out a focus on what constitutes the protagonist's growth.

A brief examination of another series by Montgomery, her Emily series, Emily of New Moon (Montgomery, 1977 [1923]), Emily climbs (Montgomery, 1953 [1925]) and Emily's quest (Montgomery, 1990 [1927]), presents another protagonist who does not grow substantially other than overcoming her own stubbornness in the final book, Emily's quest. However, the series does focus more fully on the growth of one aspect of the protagonist's development, namely her strengths as a writer. While Anne has ambitions as a writer, and eventually finds a niche for her stories for children, Emily's quest is focused more strongly on finding a literary style and recognition. Her career as a writer is foregrounded as a cause for the jealousy of her first fiancé, Dean Priest. The semi-autobiographical overtones of the young author's struggles to find an authorial voice shift this series closer to the Bildungsroman and even its subtype, the Künstlerroman, which "represents the growth of a novelist or other artist into the stage of maturity in which he recognises his artistic destiny and masters his artistic craft" (Abrams, 1981:121). She needs to accept her spiritual mate, the painter and her childhood friend, to reach any form of contentment (and maturity). Nevertheless, the series resists classification as a pure Bildungsroman, because the character does not reach new insight or maturity due to crisis.

Single novels such as Jane of Lantern Hill (Montgomery, 1954 [1937]) fail to meet the criterion of the protagonist's growing up, and, 
in The blue castle (Montgomery, 1966 [1926]), the protagonist is already grown up, disqualifying these novels from this discussion.

\subsection{Bildung in Ela Spence's Soekie series}

In South African writer Ela Spence's Soekie series from the 1950s, we again meet a protagonist in her pre-teens. The lively, sensitive but mischievous eleven-year old Soekie (alias Susarah Wilhelmina Rossouw) has brown eyes, brown straight hair and a myriad freckles:

Fyn, goudkleurige sproetjies is oor die lewendige gesiggie gesaai en haar ligbruin hare is in twee kort vlegsels gevleg wat soos twee spekvet vingertjies agter haar ore wegstaan. Twee helder rooi strikke pronk aan die punte en met elke beweging wip hulle soos vlinders vermakerig op en af.

'Jou vabond, wag, ek sal jou kry ...' (Spence, 1980 [1952]:1).17

Soekie grows up in a parsonage, with loving parents (in a South African story of that era, the patriarchal but kind father is almost a given), a brother who is working and studying, a sister in her final school year, and four-year old twin brothers. Like Anne and Emily, she too gets into trouble for letting her imagination wander when she should be working, and has a fiery temper. This temper comes into play almost immediately when the new neighbours move in and she and the son, Willie, initially argue (Spence, 1980 [1952]:1-4). While Soekie remains the protagonist, the writer compromises this role for her by merely telling the reader that Soekie is sensitive, but also by showing the reader many of the feelings of Soekie's best friend Willie throughout their initially completely platonic and innocent, but ultimately faintly romantic, if still sexually innocent, friendship.)

As with the Anne series, the protagonist grows over several books in the series, maturing over a period of five years (age 11 to 16). She does undergo varied experiences, and faces crises of sorts.

Soekie's largest personal crisis arises in Soekie en Kaptein (Spence, 1984b [1953]) when she makes a personal sacrifice -

17 Fine golden freckles are sown all over the lively little face and her light brown hair is plaited into two short pigtails that stand out behind her ears like two very fat little fingers. Two bright red ribbons flourish at the ends and with every movement they bounc saucily up and down like butterflies.

'You pest, just wait, l'll get you yet ...'] [quoting from an oft-recited Afrikaans poem] (own translation - IN) 
giving up her dearly beloved dog Kaptein, an intelligent and gentle Alsatian, to an elderly friend, Tannie Coetzee, who has become blind and needs a guide. Like Anne, she sees her duty and does it. However, this hardly constitutes a character-changing decision. It is through Tannie Coetzee that Soekie encounters both the happiness of giving and the sadness of grief: when the old lady passes away in Soekie op hoërskool (Spence, 1984c [1954]:77-82), Kaptein comes back to Soekie, but their relationship has been subtly altered.

The series tends to shift into other genres - adventure in Soekie en die tweeling (Spence, 1984a [1953]), and the school story in Soekie op hoërskool (Spence, 1984c [1954]) and Soekie en haar maats (Spence, 1974 [1954]). Soekie word sestien (Spence, 1975 [1955]) is a rather hybrid text, and as the last in the series should end with a more mature Soekie, with a greater sense of identity. In fact, Soekie only really enters a period of questioning herself and the stability of her world in this book when her elder brother gets married, altering the family dynamic. She is initially upset and jealous, unable to understand why her little world is not enough for her grown-up brother, and unwilling to share him with her future sister-in-law. She is both disturbed and fascinated by her older sister's budding romance. The novel ends with her embarking on the uncertainties of adolescence, rather than having overcome them, herself on the brink of a change in her relationship with her best friend Willie, as they shift from climbing trees together to a "kys" [going steady].

The greatest problem one encounters in classifying this series is once again a lack of a sense of personal awareness in the main character. Soekie does not question the rules laid down for her, not even with regard to what she wears, or the way in which she is told to behave when there is "company". Whatever mischief Soekie gets into, like Anne, she remains, at heart, largely unchanged. Nevertheless, the writer's depiction of Soekie's growing empathy for others (for Willie when he breaks his arm, for Tannie Coetzee in her illness and blindness, for her siblings, for a friend, Ansie, whose mother has died and for Ansie's new stepmother who is trying to win Ansie's love) does suggest some growth. It ultimately leaves Soekie more thoughtful, and, if she is not quite mature at the end of the last book in the series, she is well on her way to becoming a wellintegrated member of her society, and, indeed, to fulfilling her early promise. 


\subsection{Magda Trott's Pucki series as an exploration of the Bildungsroman concepts}

Magda Trott's Pucki (alias Hedi Sandler) is the eldest of a forester's three daughters, popular, cheerful and bold, and when she gets older, always ready to play tricks. The series traces her life from the age of four to about forty-five, when her eldest son is about to leave high school. Trott's heroine is initially exposed to parental guidance urging her to be more thoughtful and considerate, but, interestingly, the majority of her decisions are taken when she is on her own. So, for example, at the age of five, she has to recognise the situation and take the initiative and make the decision to call the fire brigade to stop a forest fire in Försters Pucki (Trott, s.a. (I):151-3). She has to make a judgement call when she meets a strange woman in the forest and helps her to gather wood, despite the prohibition against gathering wood on particular days of the week (Trott, s.a. (II):61-64). She reveals her generosity when she gives an impoverished schoolmate (Thusnelda Reichert) her shoes when she goes to school for the first time in Puckis erstes Schuljahr (Trott, s.a. (II):51) and gives Thusnelda her own Zuckertüte (a chocolate- or sweetfilled paper cone given to German schoolchildren of that era on the occasion of their first going to school), even though she has been looking forward to her chocolate all day (Trott, s.a. (II):16-17). Similarly, she has to make her own decisions when she is boarding in a different town where she goes to high school (Trott, s.a. (IV)18. In almost every case, the encounters that require her to take action bring her into contact with a world different from the security of her own blooming youth and parental home - she has glimpses of poverty, old age and deprivation in various forms. Like Soekie, she encounters death for the first time in a beloved elderly friend. She is reading from the Bible to her friend the Schmanzbäuerin, when the old woman dies (Trott, s.a. (II):154-8).

The real test of her character comes when she goes out to become a Kindermädchen, a kind of au pair or nursemaid, in a species of bridging year in Puckis erster Schritt ins Leben (Trott, s.a. (VI)). Her first job is a failure. When she manages to find a new position, she enters a family in crisis, and she has to experience a world different from the one she grew up in. On the one hand, she is attracted to the glamour radiated by her new employers (Mr. Prell is an opera

18 Pucki und ihre Freunde (Trott, s.a. (III)) and Puckis neue Streiche (Trott, s.a. $(\mathrm{V})$ ) tend more to the "school" genre and add little to this discussion. 
singer, his wife is a novelist), but on the other, she has to deal with the neglect suffered by the two sons in her charge. She is faced with a moral dilemma when one of the boys gives her a lotto ticket, and it turns out to be a winning number. Her decision to return the ticket to him so that he can collect the winnings is a hard one, since she herself has to give up her visions of travelling to all the many places she has always wanted to see. This book in the series in particular allows for real growth in the character, resulting in deeper insight into herself and her world. The book ends with her realisation of what she wants to do - namely train as a Kindergarten teacher.

The next book's title, Pucki wird eine glückliche Braut [Pucki becomes a happy bride] (Trott, s.a. (VII)), is indicative of the focus of the book - Pucki's romance. The two books that follow ${ }^{19}$ take the protagonist to new insights and growth. While Pucki als junge Hausfrau [Pucki as a young housewife] (Trott, s.a. (VIII)) might have its lighter moments in her culinary disasters, the novel (incidentally marked for young adult readers, "für junge Mädchen" as opposed to "für Kinder") addresses the sometimes complex adjustment of a young woman to marriage (complicated by the demands of her husband's profession, as he is a doctor) in a realistic way which resists sentimentalisation or a "happy ever after".

The realism of this novel is equalled in Puckis Familienglück [Pucki's familial happiness] (Trott, s.a. (IX)), when, as a young mother, Pucki hopes to take her talent for drawing into a career, but has to make some difficult decisions in choosing between her personal ambitions and the needs of her family as she slips into a series of small deceptions that ultimately threaten her marriage. Once again, the writer does not opt for a glib choice of family purely because of duty. Pucki grows enormously as she has to face her own limitations and once again has to address her desire to be the object of flattery and her hunger for glamour as opposed to exercising her real ability in human relations. Admittedly, in the last three books of the series, Pucki und ihre drei Jungen [Pucki and her three sons] (Trott, s.a. (X)), Pucki unser Mütterchen [Pucki, our little mother] (Trott, s.a. (XI)) and Puckis Lebenssommer [Pucki in the summer of her life] (Trott, s.a. (XII)), the focus shifts to the children (as in the Anne series from Anne of Ingleside onwards).

19 Pucki als junge Hausfrau [Pucki as a young housewife] (Trott, s.a. (VIII) and Puckis Familienglück [Pucki's familial happiness] (Trott, s.a. (IX). 
Magda Trott does not shy away from adult problems in some of her other series either - in her Goldköpfchen series, in Goldköpfchens großer Entschluß [Goldköpfchen's great decision] (Trott, s.a. (XIII)), the protagonist is not only widowed by the war, but takes up her former career as a photographer to support her children.

\subsection{Do these series represent the Bildungsroman genre?}

Of the three series examined, the Pucki series comes closest to meeting the criteria of the Bildungsroman. A single character has to learn more about herself to arrive at a sense of identity and a recognition of her role in her world. Pucki achieves not only a sense of self, but also a sense of harmonious belonging (as does Anne). However, unlike Anne's, Pucki's quest is ongoing, and the introduction of more complex issues relevant to young adult readers adds to the sense of real growth in the character. Incidents contribute to her growth. Soekie makes a start in growing up, and the series does contain elements of the Bildungsroman, but is not a fully fledged version of this type of text. It may be that because Soekie comes at the end of an era of didactic Bildungsromane, the author was no longer as concerned as her predecessors were with her socialisation into a particular role.

\section{Bildung in parallel: an alternative form of Bildungs- roman}

Louisa May Alcott's semi-autobiographical Little women and her Good wives (Alcott, [1868] 1947)20 do not fit the Bildungsroman genre perfectly, but do present an alternative to the serialisation of the development of a single protagonist in these books - she presents four female options in parallel in four very different sisters, Meg, Jo, Beth and Amy.

Meg is the eldest, romantic, discreetly pretty, with a few vanities and great gentleness. Jo, the second sister, is a tomboy who refuses to grow up, wilful and hot-tempered, flamboyant, and an aspirant writer. Beth, the third, is excruciatingly shy, but cheerful, quietly hard-working, sensitive and musical. Amy is vain, selfish and spoilt, but highly artistic and pretty.

20 Little women appeared in 1868, Good wives in 1871, but most people read the two books as one, as they are often published together. The 1947 edition used in the course of this study also combines the two books as one. 
The four sisters go different routes: Meg marries and has twins; Amy hopes to become an artist but marries and becomes a patroness of the arts instead; Beth hides in the shadows, destined to remain with her parents or live with her sisters, until she dies in her teens; Jo becomes a successful writer, marries - much to her own surprise and eventually runs an experimental school, for children who come from troubled backgrounds. It seems as if Alcott is exploring the different options open to American middle class girls in the late nineteenth century in her detailed exposition of these protagonists' struggles to find a balance between what they personally want, what society wants from them and their own internalisation of the codes of their society to a greater or lesser degree.

Alcott may appear to return her heroines to traditional roles, but her realism and her consideration of women working outside a home from which the father as breadwinner is conspicuously absent keeps her novel topical. Meg teaches, Jo works as a "companion" to a difficult relative, and their mother also works while effectively raising her daughters alone, even when her husband is home.

In a single novel for girls, An old-fashioned girl, Alcott (1990 [1870]) also explores the working woman and female emancipation. In a novel intended for young adults but not published in her lifetime, Diana and Persis, she was to explore fully the dilemma of career versus motherhood (Alcott, 1978) in what could be regarded as a form of Künstlerroman. Interestingly, in this novel, the obstacle to a woman's pursuit of a career, particularly as an artist, is not wifehood, but the demands of motherhood (Ebert, in Alcott, 1978:31). (Diana and Persis again follows the pattern of exploring two options in parallel, with Diana opting for her art, and Persis opting for marriage and motherhood, but this novel is not explored in this article as a Bildungsroman, because the protagonists are already adults and the novel does not follow a pattern of development.)

\section{Bildung toward what ideal?}

While in the naming of the genre, the term Bildung is generally held to refer to the maturing of the protagonist, the age-old debate of whether the function of art (especially literature for children) is to "teach" or "delight" or both tends to rear its head here. If a reader identifies with the protagonist, will he or she learn and grow vicariously with the protagonist? Let us assume, for the sake of argument, that in writing these series, as is often one of the express purposes of children's literature, the authors wanted to guide girls to learn something. What then does the reader learn? 
In all three series, there is a strongly didactic element, as the references to embracing "duty" should have made clear. In all three series, the protagonist has specific "flaws" that she is reprimanded for and actively tries to eradicate or control.

Anne is stubborn, overly imaginative, a little vain, thoughtless and not always focused on the task at hand. She has to learn that her stubbornness causes her to miss out on things; that her imagination needs to be channelled positively; that worrying about her red hair is not half as bad as worrying about what to do when one has accidentally dyed the red hair green, and how to be more focused.

Soekie is also a dreamer, and sometimes thoughtless. Soekie's mother occasionally curbs her exuberance by pointing out that a particular act could hurt someone else's feelings. When Soekie's brother is about to get married, her jealousy makes her rude and stubborn, and this time it is her friend Willie who makes her aware of the effects of her actions.

Pucki's inconsiderate behaviour and inclination to wish to play tricks are addressed most effectively, not by her parents, but by the eldest son of the head forester, who in Pucki und ihre Freunde (Trott, s.a. (III)) gives her a little partitioned box, das Himmelskästchen, into which she herself must throw a dried white bean for every good deed, and a dried black bean for every bad deed. This visible prompt to her conscience is quite effective, as her continued use of the box into her late teens in Puckis neue Streiche (Trott, s.a. (V)) confirms.

In all these cases, it is the more anti- or a-social aspects of the protagonists' characters that need to be subdued. The generic values of self-control (in particular with regard to temper), good manners and considerateness are thus emphasised in forms that many child readers are able to identify with.

But to return to duty and the expectations of the "defined social order", as Hader (1996) puts it. In these books, duty sometimes consists of a greater or lesser sacrifice of the protagonist's own desires to meet the needs of her family or those who depend on her, whether this is Marilla who is going blind, a war baby who needs care, an elderly friend, or the protagonist's husband and children. The protagonists must learn to give up possessions, ambitions and careers. It is perhaps in this point that novels of development with female protagonists differ most from such novels as Portrait of the artist as a young man. Male protagonists tend to attain insight into 
the self and embrace their ambitions (in the vocation of their choice) as part of that selfhood. Female protagonists in some of these older novels are expected to recognise a higher self in giving up their ambitions or in shifting their aspirations to meeting the needs of their significant others. ${ }^{21}$ Many male protagonists develop a self apart from society; female protagonists tend to develop a self in a socially related role - as wife, mother, sister or friend. The connectedness of the female protagonist is emphasised as an important value.

The emphasis on such connectedness and on social skills and values must be regarded as a strongly positive attribute of the "female" Bildungsroman of this era. The connectedness of these female protagonists with others, in combination with a more clearly defined sense of self (and the awareness and acceptance - indeed celebration - by the authors of their "otherness" in relation to the norms of their society) makes them role models that may still be worth emulating in many respects.

Alcott, for example, was one of the first authors to be so radical as to emphasise the need for skills in women, because such skills empower them to be valuable to their society (whether in the workplace or in the home). Some feminist critics may feel uncomfortable with the domestic realism in many of the skills that the novels discussed above depict their protagonists as learning (willingly or unwillingly), because showing girls learning to cook and sew is today often regarded as reinforcing patriarchal structures. However, such skills should perhaps rather be seen as empowering to both boys and girls, and the adoption of socially responsible roles should continue to be encouraged.

\section{Conclusion}

It would seem that, while there are novels for and about girls that do meet several of the broad criteria for the Bildungsroman, very few books meet all the criteria, despite the basic pattern of displaying the growing up of one or more protagonists. The girl protagonists do indeed have varied experiences, and learn from them; some face crises; they are brought face to face with the expectations of society.

21 Well-known books such as Susan Coolidge's Katy series (1872, 1873, 1886) (which also taps into other genres), Kate Douglas Wiggin's Rebecca of Sunnybrook Farm (1903) and Eleanor Porter's Pollyanna (1913) may also be cited as books from this era that encourage these values. Many other examples can be found. 
The books examined above suggest that single books for girls cannot be readily classified as examples of the Bildungsroman, unless the novel of parallel experience is admitted into the genre. This suggests that the possibility of a series is a more plausible form for a Bildungsroman on and for girls. An issue which problematises the genre itself is the finding that the key criterion of a protagonist who achieves a clear sense of identity and a self-actualising selfhood is either not fully met in these novels, or that selfactualisation and selfhood must be redefined to some extent for a female protagonist, to include a more socially responsible and connected form of self-actualisation (certainly in the texts looked at here). It is worth noting that in some of the seminal German examples of the adult "male" Bildungsroman, such as Goethe's Wilhelm Meister, such socially responsible self-actualisation is also advocated, but that this aspect gradually decreased in English examples (including the Joyce and Lawrence novels cited above, which were, of course, not written for children).

In the series for girls discussed here, selfhood is indissolubly linked to a woman's social roles as wife, mother, sister and nurturer. For better or worse, the socialisation of girls in these older books as nurturers tends to take precedence over a quest for independent selfhood. The interest or "conflict" in these novels lies, to a large extent, in the tensions between an emerging selfhood and the socialisation of these protagonists. The books discussed in this article reflect the existing discourses of their time, but they are also part of a literature that has been and continues to be involved in shaping the girl reader's self.

The scope of this article does not permit a detailed examination of more recent novels and series (where series are in fact written) to discover whether the protagonists are portrayed differently. It may well be that it will take another generation or two for girl's literature to depict or reflect girls' and young women's identities differently. There is clearly a place for the addition to new children's literature of Bildungsromane (single books or series) reflecting the much wider choices available to girls in socially responsible roles other than only wife and mother (or combining careers with such nurturing roles) and allowing for different kinds of self-actualisation.

When the conflicts faced by the protagonists are as universal, as practical and as easy to identify with as those faced by the protagonists in the books discussed here, these books do not date, 
despite the apparently "localised" and "period" aspects of these novels. 22 The values of self-control, good manners, considerateness and social connectedness are worth cultivating at any time and in any place.

This suggests that there is room for children's authors to revisit the genre, and to consider the genre (in individual novels or in series, perhaps in combination with other genres, such as fantasy) as a vehicle for demonstrating the path of a protagonist towards shaping both capable selfhood and a socially responsible persona. This may be particularly valuable in South African children's literature, where the continued grappling of a protagonist with his or her circumstances and, even more importantly, with him/herself within a particularly complex world, may act as an inspiration and model for readers' growth towards responsible selfhood.

\section{List of references}

ABRAMS, M.H. 1981. A glossary of literary terms. Fourth edition. New York: Holt, Rinehart \& Winston.

ALCOTT, LOUISA MAY. 1927 [1876]. Rose in bloom. New York: Grosset \& Dunlap.

ALCOTT, LOUISA MAY. 1940 [1875]. Eight cousins. Racine: Whitman.

ALCOTT, LOUISA MAY. 1947 [1868]. Little women (and Good wives). New York: Grosset \& Dunlap.

ALCOTT, LOUISA MAY. 1978. Diana and Persis. (Ed., S. Ebert). New York: Arno.

ALCOTT, LOUISA MAY. 1990 [1870]. An old fashioned girl. Harmondsworth: Puffin.

BLAKEMORE, STELLA. 1971. Kobie regeer. Sewende uitgawe. Pretoria: Van Schaik.

BLUME, JUDY. 1998. [1970] Are you there, God? It's me, Margaret. London: Pan.

BLYTON, ENID. 1947 [1941]. The twins at St. Clare's. London: Methuen.

BLYTON, ENID. 1948. [1946] First term at Malory Towers. London: Methuen.

BRATT, BERTE. s.a.(I). Alle nennen mich Pony. Frankfurt: Schneider.

BRATT, BERTE. s.a.(II). Hab Mut, Katrin! Frankfurt: Schneider.

CARPENTER, H. \& PRICHARD, M., eds. 1995. The Oxford companion to children's literature. Oxford: Oxford University Press.

CLOETE, T.T., red. 1992. Literêre terme en teorieë. Pretoria: Haum-Literêr.

22 Singer (1992:152), a Nobel Prize winner for literature, has argued that writing about a localised situation in a specific time does not hamper children's writers: "The more a writer is rooted in his environment, the more he is understood by all people; the more national he is, the more international he becomes." 
COOLIDGE, SUSAN. s.a. [1872, 1873, 1886]. All that Katy did. An omnibus of "Katy"stories: What Katy did, What Katy did at school, What Katy did next. London: Blackie.

DICKENS, CHARLES. 1981 [1850]. David Copperfield. Harmondsworth: Penguin.

HADER, S. 1996. The Victorian Web: literature, history \& culture in the Victorian Age (the Bildungsroman genre). http://www.victorianweb.org/genrehader1. html [26 August 2003].

JOYCE, J. 1978 [1916]. Portrait of the artist as a young man. London: Heinemann.

LAWRENCE, D.H. 1980 [1913]. Sons and lovers. Harmondsworth: Penguin.

MAHY, M. 1985. The catalogue of the universe. London: Dent.

MONTGOMERY, L.M. 1937 [1915]. Anne of the Island. London: Harrap.

MONTGOMERY, L.M. 1953 [1925]. Emily climbs. London: Harrap.

MONTGOMERY, L.M. 1954 [1937]. Jane of Lantern Hill. London: Harrap.

MONTGOMERY, L.M. 1965 [1939]. Anne of Ingleside. London: Harrap.

MONTGOMERY, L.M. 1966 [1926]. The blue castle. London: Harrap.

MONTGOMERY, L.M. 1975 [1919]. Rainbow Valley. London: Harrap.

MONTGOMERY, L.M. 1976 [1908]. Anne of Green Gables. London: Harrap.

MONTGOMERY, L.M. 1977 [1923]. Emily of New Moon. London: Harrap.

MONTGOMERY, L.M. 1983a [1909]. Anne of Avonlea. London: Puffin.

MONTGOMERY, L.M. 1983b [1917]. Anne's house of dreams. London: Puffin.

MONTGOMERY, L.M. 1990 [1927]. Emily's quest. London: Puffin.

MONTGOMERY, L.M. 1993 [1921]. Rilla of Ingleside. London: Puffin.

MONTGOMERY, L.M. 1994 [1936]. Anne of Windy Willows. London: Puffin.

NANCY DREW $®$ History in the making. s.a. http://www.nancydrewsleuth.com [10 October 2004].

NANCY DREW $®$ Through the years. s.a. http://www.nancydrewsleuth.com [10 October 2004].

NAUDÉ, BETTIE. 1994. Saartjie Omnibus 3. Johannesburg: Perskor .

PORTER, ELEANOR. 1937 [1913]. Pollyanna. London: Harrap.

RIED, G. 1972. Wesen und Werden der deutschen Dichtung. München: Lurz.

SCHOLTZ, M.G. 1992. Roman. (In Cloete, T.T., red. Literêre terme en teorieë. Pretoria: Haum Literêr. p. 437-446.)

SINGER, I.B. 1992. Are children the ultimate literary critics? (In Maxwell-Mahon, W.D., Titlestad, P.J.H. \& colleagues, eds. Ways with words. Johannesburg: Lexicon. p. 150-154.)

SMITH, A.L. 2002. From the drawing room to the mean streets: A feminist reading of detective fiction written by women. Johannesburg: University of the Witwatersrand. (Ph.D. thesis.)

SPENCE, ELA. 1974 [1954]. Soekie en haar maats. Derde uitgawe, tweede druk. Pretoria: Van Schaik.

SPENCE, ELA. 1975 [1955]. Soekie word sestien. Derde uitgawe, tweede druk. Pretoria: Van Schaik.

SPENCE, ELA. 1980 [1952]. Soekie. Derde uitgawe, derde druk. Pretoria: Van Schaik.

SPENCE, ELA. 1984a [1953]. Soekie en die tweeling. Derde uitgawe, derde druk. Pretoria: Van Schaik.

SPENCE, ELA. 1984b [1953]. Soekie en kaptein. Derde uitgawe, derde druk. Pretoria: Van Schaik. 
SPENCE, ELA. 1984c [1954]. Soekie op hoërskool. Vierde uitgawe, derde druk. Pretoria: Van Schaik.

STEENBERG, E. 1969. Bergpad na Eden. Pretoria: Van der Walt.

STEENBERG, E. 1978a. Wolf ja, wolf nee. Kaapstad: Tafelberg.

STEENBERG, E. 1978b. An-Alleentjie. Kaapstad: Human \& Rousseau.

STEENBERG, E. 1981. Waar is Pappa se panfluit? Kaapstad: Tafelberg.

STEENBERG, E. 1986. Slapende honde miaau nie. Kaapstad: Tafelberg.

STEENBERG, E. 1988. Wêreld in wêreld deur. Pretoria: HAUM-Literêr.

STRICKLAND, C. 1985. Victorian domesticity. Families in the life and art of Louisa May Alcott. Alabama: University of Alabama.

THE UNOFFICIAL NANCY DREW FANS WEBSITE. s.a. http://www.nancydrew sleuth.com [10 October 2004].

TROTT, MAGDA. s.a. (I) Försters Pucki. Stuttgart: Titania.

TROTT, MAGDA. s.a. (II) Puckis erstes Schuljahr. Stuttgart: Titania.

TROTT, MAGDA. s.a. (III) Pucki und ihre Freunde. Stuttgart: Titania.

TROTT, MAGDA. s.a. (IV) Pucki kommt in die höhere Schule. Stuttgart: Titania.

TROTT, MAGDA. s.a. (V) Puckis neue Streiche. Stuttgart: Titania.

TROTT, MAGDA. s.a. (VI) Puckis erster Schritt ins Leben. Stuttgart: Titania.

TROTT, MAGDA. s.a. (VII) Pucki wird eine glückliche Braut. Stuttgart: Titania.

TROTT, MAGDA. s.a. (VIII) Pucki als junge Hausfrau. Stuttgart: Titania.

TROTT, MAGDA. s.a. (IX) Puckis Familienglück. Stuttgart: Titania.

TROTT, MAGDA. s.a. (X) Pucki und ihre drei Jungen. Stuttgart: Titania.

TROTT, MAGDA. s.a. (XI) Pucki - unser Mütterchen. Stuttgart: Titania.

TROTT, MAGDA. s.a. (XII) Puckis Lebenssommer. Stuttgart: Titania.

TROTT, MAGDA. s.a. (XIII) Goldköpfchens großer Entschluß. Balve: Engelbert - Gebrüder Zimmermann.

VON WILPERT, G. 1979. Sachwörterbuch der Literatur. Sechste verb. \& erw. Aufl. Stuttgart: Kröner.

WIGGIN, KATE DOUGLAS. 1957 [1903]. Rebecca of Sunnybrook Farm. London: Black.

\section{Key concepts:}

\section{Bildungsroman}

female protagonist

girls' series: L.M. Mongomery; Ela Spence; Magda Trott; Louisa May Alcott

\section{Kernbegrippe:}

\section{Bildungsroman}

reekse vir meisies: L.M. Mongomery; Ela Spence; Magda Trott; Louisa May Alcott

vroulike protagonis 
